\title{
Post-settlement growth and body composition in relation to food availability in a juvenile tropical reef fish
}

\author{
Brigid A. Kerrigan \\ Department of Marine Biology, James Cook University, Townsville, Queensland 4811, Australia
}

\begin{abstract}
Pomacentrus amboinensis is an abundant, predominantly planktivorous reef fish which settles into a range of habitats from sheltered lagoons to exposed windward reefs. Recruits are exposed to differences in food availability as a function of the physical dynamics of the habitat. This study examines the effects of a variable food supply on somatic development and the deposition of energy reserves in recently settled fish. Food availability had a complex and significant effect on levels of energy reserves. Trends in lipid content between treatments were similar to those for somatic growth. A 3.5-fold difference in total lipid existed between fully fed and field fish. The lipid content of field fish was similar to starved fish. Trends in the water content of tissues were the inverse of those of total lipid; fish in 'poor' condition and with a slower growth rate had a relatively higher water content. Food availability had no effect on the levels of protein, but elevated levels of protein were detected in field fish compared to all experimental fish. There was a close relationship between feeding history, somatic growth, and levels of energy reserves, principally total lipid concentration.
\end{abstract}

KEY WORDS: Reef fish - Post-settlement - Lipids · Growth

\section{INTRODUCTION}

Somatic growth, levels of energy reserves, and resulting body size in recently settled reef fish have important ramifications for their subsequent survival and length of time to maturity. Variation in these demographic features has the potential to modify recruitment patterns and thereby influence the size structure of the adult reproductive population (Jones 1986, 1991). Reef fish populations are characterised by years of medium to low recruitment, and are only occasionally interrupted by years of extremely high recruitment (Williams 1983, Victor 1986, Doherty \& Williams 1988). Doherty \& Fowler (1994) demonstrated the transfer of these extreme, high recruitment years through the age classes of a reef fish population (Pomacentrus moluccensis) on the central Great Barrier Reef (GBR), Australia. While this pattern clearly demonstrates the effect of unusually high recruitment levels on the dynamics of reef fish populations it does not determine the importance of the more common, but lower, recruitment pulses. In both high and medium to low recruitment years, post-settlement processes and demographic events in the juvenile phase potentially play a decisive role in the dynamics of adult fish populations (Hixon 1991, Jones 1991).

Initially the importance of post-settlement events in determining adult abundance patterns was judged on whether they significantly modified survivorship patterns of recruits (Doherty 1983, Shulman \& Ogden 1987, Doherty \& Williams 1988). However, failure to detect an effect on survivorship does not preclude their importance. For example, post-settlement processes can affect juvenile growth rates and subsequent time to reproductive maturity (Jones 1986, Forrester 1990) by influencing food availability (Coates 1980, Koebele 1985). These post-settlement events influence the size structure and growth dynamics of juvenile fish populations and, thus, the absolute density of the reproductive population. Therefore, in size-structured populations, individual growth rates are as important as rates of survivorship in determining population trajectories 
(Werner \& Gilliam 1984). This realisation has caused a shift in emphasis away from population models based on age to models which are size specific (Werner \& Gilliam 1984, Pepin 1991).

Considering the impartance of body size, what are the principal factors that drive the growth rates of fish once they settle? The potential for growth in a postsettlement reef fish is intrinsically a product of its genotype, the effects of the individual's presettlement environment (e.g. food availability, temperature regime; McCormick \& Molony 1992), and the characteristics of the post-settlement habitat (e.g. food availability, competitive regimes, and risk of predation; Coates 1980, Ochi 1986, Hamner et al. 1988, Hixon 1991) into which they settle. The former 2 factors, combined, determine body size and body chemistry at settlement. Reef fish at settlement are variable in size and nutritional condition (as measured by total lipid, carbohydrate and protein levels). This variability has been shown in 2 recent studies of 2 species of pomacentrids (author's unpubl. data) and 1 species of mullid (McCormick \& Molony 1993). However, the specific consequences of variable size, in combination with nutritional condition at settlement, for post-settlement growth and probability of survival are yet to be addressed.

Here I examine experimentally the effects of a variable food supply on the deposition of energy reserves and somatic development in recently settled juveniles of the tropical reef fish, Pomacentrus amboinensis. $P$. amboinensis is an abundant, predominantly planktivorous reef fish, is highly site attached, and forms loose social groups. Dominance hierarchies have been shown to exist, where adults suppress the growth of subadults (Jones 1987a). This makes it an appropriate model species for analysing the inter-relationships between growth dynamics and nutritional condition, and consequences for survival and successful recruitment into the reproductive population.

\section{METHODS}

The relationship between feeding history and postsettlement growth in juvenile Pomacentrus amboinensis was determined in an aquarium-based feeding experiment. The experiment was conducted in aquaria to enable the precise manipulation of food and, therefore, permit the testing of a range of feeding regimes. A hierarchical design was employed to test the effects of feeding regime, with 3 replicate tanks nested within feeding treatments. During November 1990 newly settled $P$. amboinensis were captured from a fringing reef at Lizard Island $\left(14^{\circ} 40^{\prime} \mathrm{S}, 145^{\circ} 28^{\prime} \mathrm{E}\right)$ in the northern section of the GBR. All fish were collected from a single reef ( $40 \mathrm{~m}^{2}$ area of coral rubble) using a hand net, transported to the laboratory and held in aquaria for $2 \mathrm{~d}$ to acclimatise. During the period of acclimation, all fish were fed Artemia nauplii.

Fish of a similar size $(11$ to $13 \mathrm{~mm}$ standard length, SL) were randomly allocated to 1 of 3 feeding regimes. Fifteen fish were placed in each of the 3 tanks per feeding treatment. Each $450 \mathrm{l}$ tank (basal area = $0.68 \mathrm{~m}^{2}$, height $\left.=0.66 \mathrm{~m}\right)$ contained a bleached coral head (Pocillopora damicornis) $40 \times 40 \times 30 \mathrm{~cm}$ high, positioned on a concrete block, to provide shelter. Feeding regimes were chosen to cover a range of potential feeding scenarios, from a constant supply to intermittent pulses of food: Treatment 1, fed 4 times per day (food was always present in the aquaria); Treatment 2, fed once per day; Treatment 3, fed once every second day. Fish were fed to saturation during each feeding episode. On a daily basis, the quantity of food that fish received within each treatment was similar, with the exception of Treatment 3 when fish were starved. Pomacentrus amboinensis are predominantly planktivorous but have been observed feeding on algae. Therefore, all tanks were cleaned regularly to prevent the disproportionate growth of algae and the confounding of treatment effects. Food consisted of 36 to 48 h old Artemia nauplii (Ocean Star brand) and homogenised green prawn flesh. The proportion of homogenised prawn fed to fish was gradually increased through the course of the experiment, as fish gape increased. When fish were fed, food was dispersed throughout the tank to enable all individuals equal access. Fish were observed feeding in all areas of the tank; therefore, this method reduced the potential monopolisation of point sources by dominant individuals where food was released.

To provide a comparison between the growth dynamics of fish in the field and the laboratory fish, 15 Pomacentrus amboinensis of a similar size were placed on each of the 4 patch reefs located $15 \mathrm{~m}$ from the main reef on the leeward side of Lizard Island (at $7 \mathrm{~m}$ depth, well within this species' natural distribution). Field fish were allowed to feed on naturally available plankton. Patch reefs were $50 \times 50 \times 50 \mathrm{~cm}$ and composed of live and dead Pocillopora damicornis. P. amboinensis are highly site attached, so once established on patch reefs, they remain. However, to reduce the probability of emigration, fish were released onto reefs in the evening and a $3 \mathrm{~mm}$ mesh cage $(70 \times 70 \times 70 \mathrm{~cm})$ was placed over each reef for the first $24 \mathrm{~h}$, then removed. This ensured that the fish remained on the reef until they became familiar with their surroundings. The whole study ran for $53 \mathrm{~d}$.

Morphometrics. All fish were killed at the completion of the study, by chilling. Immediately prior to fixation or freezing, morphometric measurements were 
taken to describe the variability in somatic growth of fish between treatments, and in the field: standard length (SL) to the nearest $0.1 \mathrm{~mm}$, body depth at the pectoral fin and the anal fin, blotted wet weight to the nearest $\mathrm{mg}$ and wet weight following the removal of otoliths. Otoliths were removed to examine the effect of feeding regime on the deposition and width of daily bands. These data will be presented in a separate publication.

Body composition. A total of 8 or 9 fish from each tank within the 3 treatments and 25 fish from the 4 patch reefs were placed in Eppendorf tubes and stored in liquid nitrogen for the analysis of total lipids, total carbohydrates, and protein. Fish were freeze dried to a stable weight to derive water content, expressed as $\mathrm{mg} \mathrm{g}^{-1}$ wet wt. Each fish was then homogenised in $100 \mathrm{mM}$ sodium chloride $(\mathrm{NaCl})$ solution at 0 to $4^{\circ} \mathrm{C}$. Dry weight was used to determine the volume of $\mathrm{NaCl}$ required (Hopkins et al. 1984). All analyses were carried out in duplicate, and blanks were run simultaneously. Proteins were measured colorimetrically using the method outlined in Bradford (1976). Total lipids (neutral and polar) were determined using a chloroform:methanol extraction, detailed in Mann \& Gallagher (1985). Total carbohydrates were extracted using a modification of the method used by Mann \& Gallagher (1985) and outlined in McCormick \& Molony (1992).

Muscle development. Five fish from each tank within the 3 treatments, and 3 from each patch reef (field fish) were used to describe the variability in muscle fibre development. A section of the dorsal muscle block (musculus carinatus dorsalis) posterior to the first anal fin spine was fixed in formalin acetic acid calcium chloride (FAACC). Sections ( $6 \mu \mathrm{m}$ thick) were stained in haematoxylin and eosin. The maximum diameter of 100 fibres within the muscle block were measured. A pilot study showed that there was minimal variability between sections from within a fish, therefore fibres were measured within a single section. Muscle fibres were grouped into $5 \mu \mathrm{m}$ size classes $(0-4.9 \mu \mathrm{m}$, 5-9.9 $\mathrm{m}, 10-14.9 \mu \mathrm{m}$, etc.).

\section{RESULTS}

\section{Morphometrics}

Somatic growth of juvenile Pomacentrus amboinensis was strongly influenced by food availability (Fig. 1). Standard length, and body depth at the pectoral and anal fin all differed significantly among treatments including field fish inhabiting natural patch reefs (Table 1). Growth (expressed as an increase in SL over the course of the experiment, in $\mathrm{mm} \mathrm{d}^{-1}$ ) was greatest
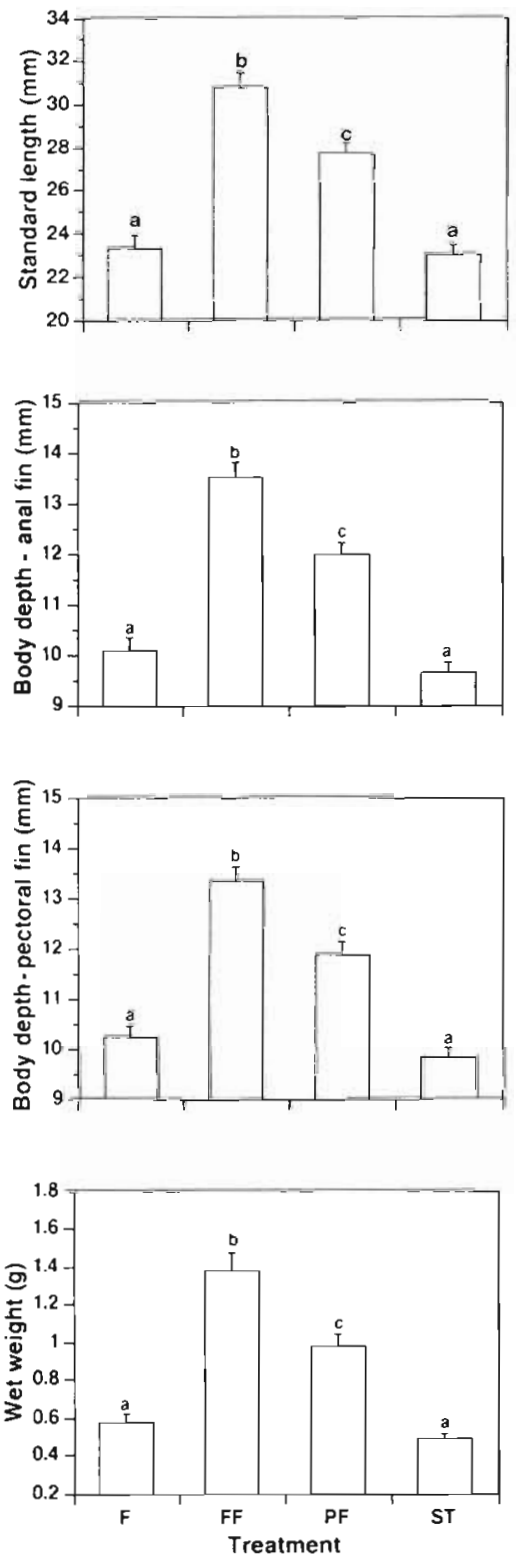

Fig. 1. Pomacentrus amboinensis. Changes in the growth of juvenile fish under 3 feeding treatments compared to field fish. Mean standard length, body depth at the anal and pectoral fins, and wet weight. Error bars are standard errors. Feeding treatments: $F$, field fish; FF, fully fed; PF, partially fed; ST, starved every second day. Means with a common letter are not significantly different at the 0.05 level (Tukey's HSD). Experiment ran for $53 \mathrm{~d}$

in fully fed (FF) fish and least in fish starved every second day (ST) and field fish. ST and field fish displayed very similar growth rates $(0.2 \pm 0.009$ and $0.21 \pm 0.015$ $\mathrm{mm} \mathrm{d}^{-1}$, respectively), suggesting recently settled fish on patch reefs experience food shortages or under such conditions are more physically active. In contrast, fish that were fully fed and partially fed (PF) displayed mean growth rates of $0.35 \pm 0.009$ and $0.29 \pm 0.015 \mathrm{~mm}$ 
Table 1. Pomacentrus amboinensis. Summary of ANOVA on the 4 variables measured to determine the effects of feeding treatment and tanks on the growth of juvenile $P$. amboinensis. Residual analysis was used to check assumptions of ANOVA

(Snedecor \& Cochran 1980). Data are not transformed

\begin{tabular}{|llrrr|}
\hline Variable & Source & df & MS & Pr $>F$ \\
\hline Standard & Treatment & 3 & 502.38 & 0.0001 \\
length & Tank (treatment) & 9 & 19.65 & 0.1084 \\
& Residual & 155 & 11.96 & \\
Body depth & & & & \\
$\quad$ Pectoral & Treatment & 3 & 95.82 & 0.0001 \\
fin & Tank (treatment) & 9 & 3.78 & 0.0880 \\
& Residual & 155 & 2.19 & \\
Anal fin & Treatment & 3 & 117.96 & 0.0001 \\
& Tank (treatment) & 9 & 4.35 & 0.0538 \\
& Residual & 155 & 2.27 & \\
Wet weight & Treatment & 3 & 6.15 & 0.0001 \\
& Tank (treatment) & 9 & 0.24 & 0.1209 \\
& Residual & 155 & 0.15 & \\
\hline
\end{tabular}

$\mathrm{d}^{-1}$, respectively. FF fish grew approximately 1.7 times faster than the field and ST fish. Similarly, marked differences in weight among treatments were recorded.

Dominant individuals attempted to monopolise access to food despite its uniform distribution throughout the tank. Aggressive interactions were observed between larger, dominant individuals and the smaller, subordinate juveniles within $14 \mathrm{~d}$ of the experiment starting. As a consequence of these aggressive interac-

Table 2. Pomacentrus amboinensis. Summary of ANOVA on all 4 biochemical variables measured, to determine the effects of feeding treatment and tanks on the body chemistry of juvenile $P$. amboinensis. Residual analysis was used to check assumptions of ANOVA (Snedecor \& Cochran 1980). Data are not transformed

\begin{tabular}{|llrrr|}
\hline Variable & Source & df & MS & Pr $>F$ \\
\hline Water & Treatment & 3 & 32670.19 & 0.0001 \\
& Tank (treatment) & 9 & 304.84 & 0.1904 \\
& Residual & 89 & 214.25 & \\
Carbohydrate & Treatment & 3 & 48.98 & 0.0001 \\
& Tank (treatment) & 9 & 1.64 & 0.0514 \\
& Residual & 89 & 13.51 & \\
Lipid & Treatment & 3 & 5864.68 & 0.0001 \\
& Tank (treatment) & 9 & 44.52 & 0.5596 \\
& Residual & 89 & 51.49 & \\
Protein & Treatment & 3 & 180.94 & 0.0255 \\
& Tank (treatment) & 9 & 35.92 & 0.2239 \\
& Residual & 89 & 26.64 & \\
\hline
\end{tabular}

tions the dominant fish in each tank obtained a greater size by the completion of the experiment. FF fish had a mean weight of $1.38 \mathrm{~g}, 0.8$ to $0.89 \mathrm{~g}$ greater than ST and field fish. Size hierarchies were observed in all tanks. The greatest variability in standard length occurred in the FF treatment (mean \% coefficient of variation of 64.05). Variability in the PF (\% CV of 42.13) and ST (\% CV of 31.41) treatments were very similar.

\section{Body composition}

Feeding regime had a more complex effect on the levels of energy reserves than on somatic growth. Significant treatment effects were detected for all biochemical constituents (Table 2). Variability among treatments was most accentuated in total lipid content (Fig. 2). A 3.5-fold difference in total lipid existed between FF fish (43.87 $\mathrm{mg} \mathrm{g}^{-1}$ ) and field fish (12.37 $\mathrm{mg}$ $\left.\mathrm{g}^{-1}\right)$. Furthermore, fish from the PF treatment contained 2.5 times as much total lipid as ST fish. Trends in lipid content between treatments were similar to those for somatic growth. The lipid content of field fish did not differ significantly from ST fish (Fig. 2, Tukey's HSD).

Trends in the water content of tissues were the inverse of those of total lipid. Fish in 'poor' condition had a relatively higher water content. Significant differences were detected among all treatments (Table 2, Fig. 2). Field fish had the highest mean water content (764.25 $\left.\mathrm{mg} \mathrm{g}^{-1}\right)$, FF fish the lowest $\left(686.35 \mathrm{mg} \mathrm{g}^{-1}\right)$.

In contrast to total lipid and water content, the carbohydrate levels within juvenile Pomacentrus amboinensis did not display the same patterns in relation to treatment. FF and PF fish had significantly higher carbohydrate levels than fish from the ST treatment, but were not significantly different from one another (Fig. 2, Tukey's HSD).

Protein levels did not differ significantly among experimental treatments (Fig. 2). Starved fish showed a relative increase in levels of protein compared to FF and PF fish. Higher levels were detected in field fish from the leeward patch reefs, than experimental fish (Fig. 2, Tukey's HSD) with a 1.1-fold difference in protein concentration.

\section{Muscle development}

Feeding regime influenced the growth and development of muscle fibres in juvenile Pomacentrus amboinensis. Fish in the field had a bimodal normal frequency distribution with peaks at 15 to $25 \mu \mathrm{m}$ and 35 to $45 \mu \mathrm{m}$, and a maximum fibre diameter of $60 \mu \mathrm{m}$ 

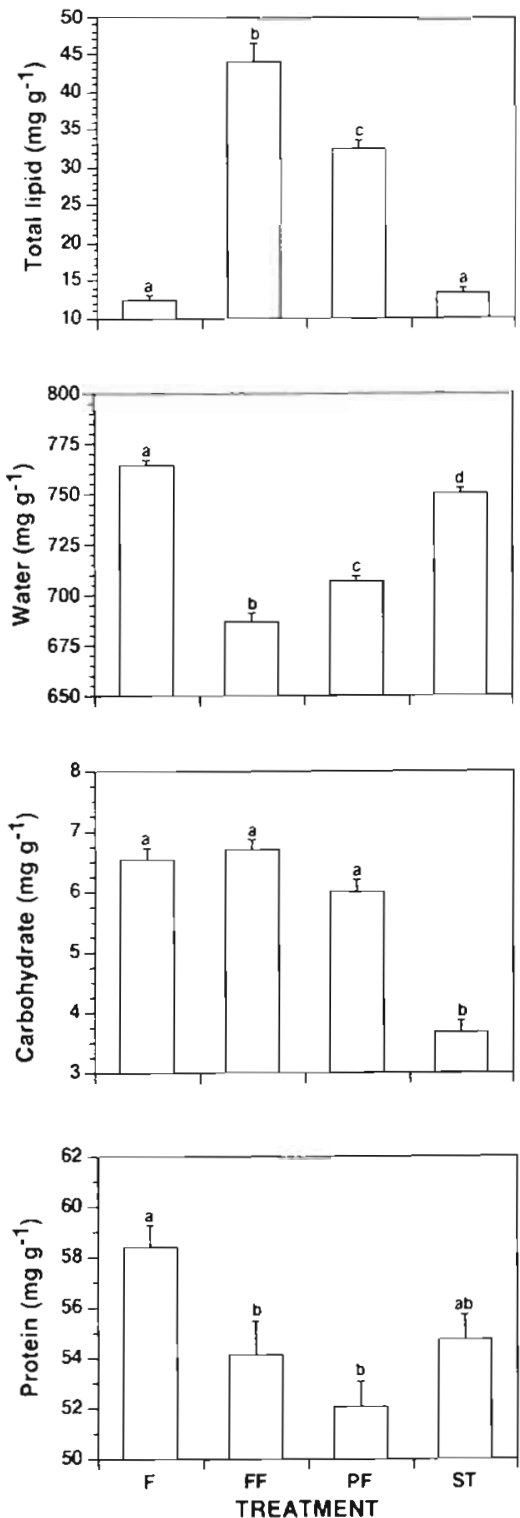

Fig. 2. Pomacentrus amboinensis. Changes in the body chemistry of juvenile fish under 3 feeding treatments compared to field fish. Concentration of total lipid, water, total carbohydrate, and protein in $\mathrm{mg} \mathrm{g}^{-1}$ wet weight (symbols and treatment codes as for Fig. 1). Experiment ran for $53 \mathrm{~d}$

(Fig. 3). Muscle fibre frequency distributions from all fish within the experimental treatments were skewed; maximum fibre diameter in FF and PF fish $(100 \mu \mathrm{m}$ and $130 \mu \mathrm{m}$, respectively) was greater than in ST individuals $(85 \mu \mathrm{m})$. ST and PF fish exhibited bimodal frequency distributions, ST fish had peaks in muscle fibre size at 10 to $20 \mu \mathrm{m}$ and 35 to $45 \mu \mathrm{m}$, PF fish peaked at 20 to $30 \mu \mathrm{m}$ and 40 to $50 \mu \mathrm{m}$. In PF fish, $11.7 \%$ of the fibres were greater than $60 \mu \mathrm{m}$ in diameter, similar to FF fish $(9.9 \%)$, but contrasting with only $3.3 \%$ in ST fish. This pattern suggests that muscle fibre growth is
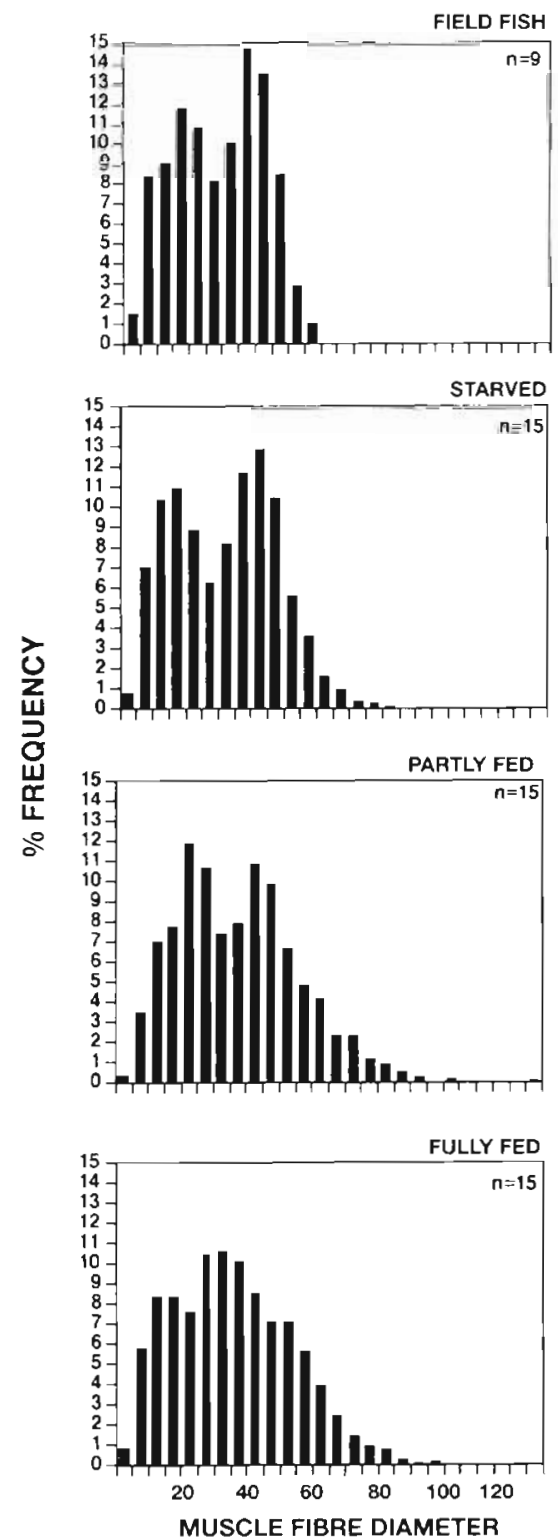

Fig. 3. Pomacentrus amboinensis. Size-frequency distributions of muscle fibres (in $5 \mu \mathrm{m}$ size classes) from juvenile fish, from each feeding treatment and the field. Experiment ran for $53 \mathrm{~d}$

somewhat restricted in field and ST fish relative to FF and PF juveniles.

\section{DISCUSSION}

This study demonstrated the inter-relationships between food availability, body chemistry, and resulting somatic growth in a recently settled, juvenile tropical reef fish. Four principal findings emerged. (1) Feeding history strongly influenced the growth of post-settle- 
ment juvenile Pomacentrus amboinensis. (2) In contrast, the response of muscle fibre recruitment and growth to variable feeding regimes was conservative (3) Size hierarchies developed within each tank. The coefficient of variation for standard length varied between treatments, and was the highest in groups of fish with an abundant food supply. (4) Complex changes occurred in the body chemistry that were partly explained by feeding regime.

The somatic growth rate and deposition of total lipid reserves in recently settled Pomacentrus amboinensis reflected their variable feeding histories. Partially fed and fully fed juveniles attained a larger size, weighed more, and exhibited higher concentrations of total lipid in their tissues than starved and field fish. A larger size and higher levels of energy reserves (total lipids) for a given post-settlement age confers a number of advantages over smaller conspecifics. The risk of predation, the outcome of competitive or aggressive interactions with conspecifics, and subsequent growth are widely reported as being size dependent (Rice et al. 1987 , Miller et al. 1988, Pepin 1988/1989, Tsukamoto et al. 1989). Jones $(1984,1986,1987 \mathrm{a}$, b) provided a mechanism by which these post-settlement events potentially modify recruitment patterns, by determining time to reproductive maturity and therefore recruitment into the adult reef fish population. This mechanism is particularly relevant in size-structured populations, where size primarily determines position in the social hierarchy and subsequent growth rate. Extensive evidence exists for a range of species that food supplementation enhances juvenile growth, reducing the time to reproductive maturity (for bass, Gutreuter \& Anderson 1985; trout, Abbott \& Dill 1989; and pomacentrids, Jones 1986, Forrester 1990). The growth rates of well-fed juveniles in this experiment suggest that, in the absence of adults and with an abundant food supply, recruits have the ability to reach reproductive maturity in their first year. Reproductive maturity of $P$. amboinensis has been recorded at $50 \mathrm{~mm} \mathrm{SL}$ in the southern GBR (Jones 1986) and $45 \mathrm{~mm}$ SL in the northern GBR (author's unpubl. data).

The growth rate of newly settled reef fish is particularly important in size-structured populations. Size hierarchies, once established, play a prominent role in determining the potential growth of individuals (Werner \& Gilliam 1984). Evidence exists for the social control of feeding regime of subordinate individuals through dominants controlling the feeding rate and quality of food eaten (pomacentrids, Coates 1980, Jones 1987a; salmonids, Metcalfe 1986, McCarthy et al. 1992). This study showed that, in the presence of an abundant food supply (the fully fed treatment), marked size hierarchies were established. Once size hierarchies are established they remain stable (Bachman.
1984, Forrester 1990). Furthermore, subordinates in a social group experience physiological stress which reduces their growth efficiency (Wirtz \& Davenport 1976, Abbott \& Dill 1989, Boisclair \& Leggett 1989, Pickering 1993). Therefore, post-settlement factors which influence the quality and quantity of food consumed by an individual act individually or synergistically to influence growth efficiency. In the absence of dominance hierarchies that regulate growth, compensatory growth in juvenile stages of pelagic and benthic fish species occurs. McCormick \& Molony (1992) showed that pre-settlement mullids that were initially starved and then refed grew and attained a size and condition status similar to fish that had been constantly fed. This compensatory growth is possible because intraspecific interactions play a very minor role in the growth dynamics of these species. The plasticity in growth is principally governed by food availability, which in the pelagic environment is primarily driven by hydrological features (Kingsford et al. 1991), and the individual's ability to obtain that food. Hence, their growth regime is opportunistic in contrast to reef fish recruiting into size-structured populations.

Muscle growth in juvenile Pomacentrus amboinensis showed a conservative response to fluctuations in food availability. Despite the marked differences in final standard length and weight of fish between treatments, only small differences in muscle growth occurred. However, fully and partially fed fish had a greater proportion of larger diameter muscle fibres (>60 $\mathrm{\mu m}$ ) than field fish. This result suggests that muscle growth via an increase in muscle fibre size was restricted in fish under sub-optimal feeding regimes. Alternatively, muscle development has been modified by the physical conditions experienced by fish in the field (e.g. sustained swimming in currents). Conservancy in muscle growth has also been recorded in experimental manipulations of trout and bluntnose minnow, where temperature and feeding regimes had a marked influence on somatic growth, but only a slight or negligible influence on muscle fibre diameter frequencies (Weatherly \& Gill 1985). In juvenile teleosts, muscle growth also occurs through the recruitment of new fibres developing from myosatellites (Weatherly et al. 1988, Kundu \& Mansuri 1990). The relative importance of the 2 modes of muscle growth, increase in fibre diameter and the recruitment of new fibres, is species and size specific. In this study, all juvenile $P$. amboinensis, irrespective of feeding regime, had high proportions of recruiting muscle fibres, denoted by the 5 and $10 \mu \mathrm{m}$ size classes. Similar results were found in juvenile rainbow trout, where fibre recruitment occurs independently of somatic growth rate (Weatherly et al. 1980). In contrast, McCormick \& Molony (1992) showed that feeding regime during the 
pre-settlement phase in mullids determines both somatic growth and muscle development by altering the recruitment rate of new fibres and the growth rate of existing fibres. Enhanced muscle development would confer advantages in terms of swimming ability, predator avoidance and maintenance of position in high currents during feeding. Based on this premise, all juvenile fish from the experiment, irrespective of feeding history, appear to have fairly similar swimming abilities.

The response of individual fish to stress (aggressive interactions, food shortages) is, in part, a function of their nutritional condition or body chemistry. Lipids are a principal energy reserve in teleosts, and are often the first components to be mobilised during periods of stress (Driedzic \& Hochachka 1978). In this study, juvenile Pomacentrus amboinensis with an abundant food supply laid down 3.5 times more lipid in their tissues than fish growing in the field. Within the well-fed treatment the dominant individuals had higher lipid levels, presumably conferring energetic and physiological advantages. Juvenile reef fish with elevated lipid levels can mobilise such reserves and thereby sustain optimal growth during periods of stress. Therefore, the effect of ambient food levels on the growth dynamics of a fish will depend, in part, on the individuals nutritional condition or body chemistry. This has important ramifications for reef fish where the outcome of post-settlement processes such as intraspecific interactions, risk of predation, and time to reproductive maturity are all size dependent (Jones 1991).

Patterns in protein and carbohydrate levels cannot be interpreted so clearly. Within the experimental treatments, starved fish had a significantly lower concentration of carbohydrate than fed and partially fed fish. The relatively low levels of carbohydrate reserves in starved fish suggests that carbohydrates are being mobilised to provide a rapid supply of energy. However, field fish, although approximately $3 / 4$ the size of the fully and partially fed fish, contained similar concentrations of carbohydrate. The patterns in the levels of carbohydrate in the aquarium and field fish must be viewed cautiously, as carbohydrate can be synthesised from either lipid or protein during periods of starvation (Love 1980).

Alternatively, Black \& Love (1988) reported that carbohydrate levels in cods were influenced by stress of capture, which resulted in a rapid decrease in muscle glycogen. Stress results in changes, for example in glucose and glycogen in fish tissues (Wieser et al. 1986 , Schwalme \& Mackay 1991), but does not alter the overall concentration of total carbohydrate which was measured in this study. All Pomacentrus amboinensis from the aquaria and the patch reefs in the field were captured and killed as quickly as possible to minimise stress. Therefore, the carbohydrate levels measured are assumed to be the true levels present in fish tissue.

In contrast to lipids, proteins are generally conserved, being the last energy reserve to be mobilised during periods of stress (Love 1980, Molony 1993). Feeding history had no significant effect on the absolute quantity of protein per individual fish. However, there is a trend towards an inverse relationship between protein and lipid. Starved and field fish had relatively higher protein levels and less lipid than fully and partially fed fish. Weatherly \& Gill (1983) have documented a similar relationship in juvenile rainbow trout, raised under variable food and temperature regimes. This trend towards more protein in field fish compared to fish reared in aquaria may also relate to fundamental differences in the activity levels. Alternatively, Wood et al. (1957) proposed that the higher fat content and the lower protein levels in juvenile salmonids raised in a hatchery compared to wild caught fish were due to differences in diet. The similarity in lipid and protein levels between starved and field fish suggests that both activity levels and diet (quantity and quality) are influencing body chemistry.

This experiment has shown that feeding regime influences the growth dynamics and total lipid levels of juvenile Pomacentrus amboinensis in a predictable way. Fish growing under conditions of an abundant food supply were able to maintain higher relative growth rates, in addition to laying down greater fat reserves, than those with a limited food supply. Information on the biochemical composition (especially lipid and water content) of reef fish at different stages of their life history will give ecologists insight into the potential effects of past-settlement processes on the growth and survival potential of individuals. It has been shown for a wide range of commercially important species (reef, pelagic and freshwater taxa) that somatic growth and sensory development rates, and subsequent survival of larval and juvenile fish is, in part, a function of their body chemistry (lipid content, fatty acid profile, triacylglycerol levels) (Love 1980, Chambers et al. 1989, Sieg 1992). Therefore, nutritional condition may play a vital role in modifying the effects of demographic events during the immediate post-settlement phase. Assessing the biochemical composition of reef fish in experiments that test the effect(s) of post-settlement processes, in addition to collecting growth and mortality estimates, will play a central role in enhancing ecologists understanding of reef fish population dynamics.

Acknowledgements. This research was funded by an Australian Research Council minor grant. Logistic support was provided by the Department of Marine Biology, James Cook University. I thank J. H. Choat, G. Jones, M. Hixon, M. 
McCormick, M. Milicich and 3 anonymous reviewers for their invaluable comments on the manuscript. Thanks to J McIlwain, $V$. Hall and $L$. Axe for their enthusiastic and energetic assistance in the field. I thank M. and L. Pearce, L. Vail and A. Hoggett for making Lizard Island a productive and enjoyable place to work. This paper is a contribution from the Lizard Island Research Station, a facility of the Australian Museum.

\section{LITERATURE CITED}

Abbott, J. C., Dill, L. M. (1989). The relative growth of dominant and subordinate juvenile steelhead trout (Salmo gairdneri) fed equal rations. Behaviour 108: 104-113

Bachman, R. A. (1984). Foraging behaviour of free-living wild and hatchery brown trout in a stream. Trans. Ann. Fish. Soc. 113: $1-32$

Black, D., Love, R. M. (1988). Estimating the carbohydrate reserves in fish. J. Fish Biol. 32: 335-340

Boisclair, D., Leggett, W. C. (1989). Among-population variability of fish growth: influence of the quantity of food consumed. Can. J. Fish. Aquat. Sci. 46: 457-467

Bradford, M. M. (1976). A rapid and sensitive method for the quantitation of microgram quantities of protein utilizing the principle of protein-dye binding. Analyt. Biochem. 72: $248-254$

Chambers, R. C., Leggett, W. C., Brown, J. A. (1989). Egg size female effects, and the correlations between early life history traits of capelin, Mallotus villosus: an appraisal at the individual level. Fish. Bull. U.S. 87: 515-523

Coates, D. (1980). Prey-size intake in humbug damselfish Dascyllus aruanus (Pisces, Pomacentridae) living within social groups. J. Anim. Ecol. 49: 335-340

Doherty, P. J. (1983). Tropical territorial damselfishes: is density Iimited by aggression or recruitment? Ecology 64 $176-190$

Doherty, P. J., Fowler, A. J. (1994). An empirical test of recruitment-limitation in a coral reef fish. Science 263: 935-939

Doherty, P. J., Williams, D. McB. (1988). The replenishment of coral reef fish populations. Oceanogr. mar. Biol. A. Rev. 26: $487-551$

Driedzic, W. R., Hochachka, P. W. (1978). Metabolism in fish during exercise. In: Hoar, W. S., Randall, D. J. (eds.) Fish physiology, Vol. VII, Locomotion. Academic Press, London, p. 503-543

Forrester, G. E. (1990). Factors influencing the juvenile demography of a coral reef fish. Ecology 71: 1666-1681

Gutreuter, S. J., Anderson, R. O. (1985). Importance of body size in the recruitment process in largemouth bass populations. Trans. Am. Fish. Soc. 114: 317-327

Hamner, W. M., Jones, M. S., Carleton, J. H., Hauri, I. R., Williams, D. McB. (1988). Zooplankton, planktivorous fish, and water currents on a windward reef face: Great Barrier Reef, Australia. Bull. mar. Sci. 42: 459-479

Hixon, M. A. (1991). Predation as a process structuring coral reef fish communities. In: Sale, P. F. (ed.) The ecology of fishes on coral reefs. Academic Press, London, p. 475-500

Hopkins, C. C. E., Seiring, J. V., Nyholmen, O. (1984). Ecological energetics from total lipid and total protein: fact and artifact using a gravimetric method for lipid and a biuret method for protein. Oceanogr. mar. Biol. A. Rev. 22 : $211-261$

Jones, G. P. (1984). Population ecology of the temperate reef fish Pseudolabrus celidotus Bloch \& Schneider (Pisces: Labridae). II. Factors influencing adult density. J. exp. mar. Biol. Ecol. 75: 277-303
Jones, G. P. (1986). Food availability affects growth in a coral reef fish. Oecologia 70: 136-139

Jones, G. P. (1987a). Competitive interactions among aduits and juveniles in a coral reef fish. Ecology 68: 1534-1547

Jones, G. P. (1987b). Some interactions between residents and recruits in two coral reef fishes. J. exp. mar. Biol. Ecol. 114: $169-182$

Jones, G. P. (1991). Postrecruitment processes in the ecology of coral reef fish populations: a multifactorial perspective. In: Sale, P. F. (ed.) The ecology of fishes on coral reefs. Academic Press, London, p. 294-327

Kingsford, M. J., Wolanski, E., Choat, J. H. (1991). Influence of tidally induced fronts and langmuir circulations on distribution and movements of presettlement fishes around a coral reef. Mar. Biol. 109: 167-180

Koebele, B. P. (1985). Growth and the size hierarchy effect: an experimental assessment of three proposed mechanisms; activity differences, disproportional food aquisition, physiological stress. Environ. Biol. Fish 12: 181-188

Kundu, R., Mansuri, A. P. (1990). Growth dynamics of myotomal muscle fibres in a carangid, Caranx malabaricus (Cuv. et Val.). J. Fish Biol. 36: 21-27

Love, R. M. (1980). The chemical biology of fishes, Vol. 2, Advances 1968-1977. Academic Press, London

Mann, K., Gallagher, B. M. (1985). Physiological and biochemical energetics of larvae of Teredo navalis L. and Bankia gouldi (Bartsch) (Bivalvia: Teredinidae). J. exp. mar. Biol. Ecol. 85: 211-228

McCarthy, I. D., Carter, C. G., Houlihan, D. F. (1992). The effect of feeding hierarchy on individual variability in daily feeding of rainbow trout, Onchorhynchus mykiss (Walbaum). J. Fish Biol, 41: 257-263

McCormick, M. I., Molony, B. W. (1992). Effects of feeding history on the growth characteristics of a reef fish at settlement. Mar. Biol. 114: 165-173

McCormick, M. I., Molony, B. W. (1993). Quality of the reef fish Upeneus tragula (Mullidae) at settlement: is size a good indicator of condition? Mar. Ecol. Prog. Ser. 98: 45-54

Metcalfe, N. B. (1986). Intraspecific variation in competitive ability and food intake in salmonids: consequences for energy budgets and growth rates. J. Fish Biol. 28: 525-531

Miller, T. J., Crowder, L. B., Rice, J. A., Marschall, E. A. (1988). Larval size and recruitment mechanisms in fishes: toward a conceptual framework. Cân. J. Fish. Aquat. Sci. 45: $1657-1670$

Molony, B. W. (1993). Effects of feeding history on mobilisation and deposition of body constituents and on growth in juvenile Ambassis vachelli (Pisces: Chanididae). Mar. Biol. 116: 389-397

Ochi, H. (1986). Growth of the anemonefish Amphiprion clarkil in temperate waters, with special reference to the influence of settling time on the growth of 0 -year olds. Mar. Biol. 92: 223-229

Pepin, P. (1988/1989). Predation and starvation of larval fish: a numerical experiment of size- and growth-dependent survival. Biol. Oceanogr 6: 23-44

Pepin, P. (1991). Effect of temperature and size on development, mortality, and survival rates of the pelagic early life history stages of marine fish. Can. J. Fish. Aquat. Sci. 48: 503-518

Pickering, A. D. (1993). Growth and stress in fish production. Aquaculture 111: 51-63

Rice, J. A., Crowder, L. B., Holey, M. E. (1987). Exploration of mechanisms regulating larval survival in Lake Michigan bloater: a recruitment analysis based on characteristics of individual larvae. Trans. Am. Fish. Soc 116: 703-718 
Schwalme, K., Mackay, W. C. (1991). Mechanisms that elevate the glucose concentration of muscle and liver in yellow perch (Perca flavescens Mitchill) after exercisehandling stress. Can. J. Fish. Aquat. Sci. 69: 456-461

Shulman, M. J., Ogden, J. C. (1987). What controls tropical reef fish populations: recruitment or benthic mortality? An example in the Caribbean reef fish Haemulon flavolineatum. Mar. Ecol. Prog. Ser. 39: 233-242

Sieg, A. (1992). Histological study of organogenesis in the young stages of the mesopelagic fish Vinciguerria (Photichthyidae, Pisces). Bull. mar. Sci. 50: 97-107

Snedecor, G. W., Cochran, W. G. (1980). Statistical methods 7 th edn. Iowa State Univ. Press, Ames

Tsukamoto, K., Kuwada, H., Hirokawa, J., Oya, M., Sekiya, S., Fujimoto, H., Imaizumi, K. (1989). Size-dependent mortality of red sea bream, Pagrus major, juveniles released with fluorescent otolith-tags in News Bay, Japan. J. Fish Biol. 35 (suppl. A): 59-69

Victor, B. C. (1986). Larval settlement and juvenile mortality in a recruitment-limited coral reef fish population. Ecol. Monogi. 56: 145-160

Weatherly, A. H., Gill, H. S. (1983). Relative growth of tissues at different somatic growth rates in rainbow trout Salmo gairdneri Richardson. J. Fish Biol. 22: 43-60

Weatherly, A. H., Gill, H. S. (1985). Dynamics of increase in muscle fibres in fishes in relation to size and growth.

This article was presented by D. M. Alongi (Senior Editorial Advisor), Townsville, Australia
Experientia 41: 353-354

Weatherly, A. H., Gill, H. S., Lobo, A. F. (1988). Recruitment and maximal muscle growth and ultimate size. J. Fish Biol. 33: $851-859$

Weatherly, A. H., Gill, H. S., Rogers, S. C. (1980). Growth dynamics of mosaic muscle fibres in fingerling rainbow trout (Salmo gairdners) in relation to somatic growth rate. Can. J. Zool. 58: 1535-1541

Werner, E. E., Gilliam. J. F. (1984). The ontogenetic niche and species interactions in size-structured populations. A. Rev. Ecol. Syst. 15: 393-425

Wieser, W., Koch, F., Drexel, E., Platzer, U. (1986). 'Stress' reactions in teleosts: effects of temperature and activity on anaerobic energy production in roach (Rutilus rutilus L.). Comp. Biochem. Physiol. 83A: 41-45

Williams, D. McB. (1983). Daily, monthly, and yearly variability in recruitment of a guild of coral reef fishes. Mar. Ecol. Prog. Ser. 10: 231-237

Wirtz, P., Davenport, J. (1976). Increased oxygen consumption in blennies (Blennius pholis L.) exposed to their mirror images. J. Fish Biol. 9: 67-74

Wood, E. M., Yasutake, W. T., Woodall, A. N., Halver, J. E. (1957). The nutrition of salmonoid fishes I. Chemical and histological studies of wild and domestic fish. J. Nutr. 61: $465-478$

Manuscript first received: January 26, 1994

Revised version accepted: April 25, 1994 